Caltová, J. (2011). Historický vývoj úlohy psaného textu ve vybraných metodách vyučování cizím jazykům. In T. Janík, P. Knecht, \& S. Šebestová (Eds.), Smíšený design v pedagogickém výzkumu: Sborník př́spěvkỉ z 19. výročni konference České asociace pedagogického výzkumu (s. 526-531). Brno: Masarykova univerzita.

Dostupné z: http://www.ped.muni.cz/capv2011/sbornikprispevku/caltova.pdf

doi: 10.5817/PdF.P210-CAPV-2012-4

\title{
Historický vývoj úlohy psaného textu ve vybraných metodách vyučování cizím jazykům
}

\author{
Historical development of the role of a written text in selected language teaching \\ methods
}

Julia Caltová

\begin{abstract}
Abstrakt: S ekonomickým, politickým a kulturním rozvojem společnosti nabývá na důležitosti potřeba hledání odpovídajících metod vyučování cizím jazykům. Každá nová metoda před sebe klade odlišný cíl a podle toho se různí i prostředky jeho dosažení. Př́spěvek je věnován analýze role psaného textu, jeho forem, funkcí a míry využití ve vybraných vyučovacích metodách od středověku po současnost. Př́íspěvek je výtažkem z kapitoly disertační práce autorky, která se zabývá otázkou textu jako prostředku a cíle utváření komunikativní kompetence při výuce cizích jazyků, a představuje historický úvod do problematiky práce s textem.
\end{abstract}

Klíčová slova: metodický směr, cíl jazykového vyučování, psaný text, dovednost čtení, analytická metoda, syntetická metoda

\begin{abstract}
When a society develops economically, politically and culturally, searching for an appropriate methodological approach in foreign language teaching becomes more and more essential. Each new approach puts a different goal and thus chooses different means of achieving it. The article is devoted to analysis of the role of a written text, of its forms, functions and extent of its use in selected language teaching methods since the Middle Ages up to the present times. As the author deals with the question of a text as an aim and means of the communicative competence formation, the article represents a summary of one of her thesis' chapters and a certain historical introduction to issues of a text in foreign language teaching.
\end{abstract}

Keywords: methodological approach, goal of language learning, written text, reading skills, analytical method, synthetic method

\section{1 Úvod}

Během posledních několika století se vystřídala řada metodických směrů, počínaje tradičním gramaticko-překladovým, jehož kořeny sahají až od středověku, přes relativně málo využívané netradiční techniky výuky cizích jazyku až po komunikativní metodu, v dnešní době dominantní. Celkově můžeme sledovat protikladnost dvou klíčových př́istupů k výuce: syntetického a analytického, které se stř́daly a různě se kombinovaly v průběhu několika století. Je vhodné připomenout, že syntéza je proces sjednocení roztř́štěných částí, zatímco analýza naopak představuje postup členění celku na jednotlivé části a jejich rozbor. Ke klasickému syntetickému prŕstupu můžeme přiřadit gramaticko-překladovou metodu a její varianty. K analytické koncepci ve své krajní formě patří př́má metoda. Kromě diametrálně 
protikladného př́stupu k procesu výuky, který se projevoval $\mathrm{v}$ odlišném pojetí úlohy mluvnice, vztahu k mateřštině žáků, přeceňování nebo naopak zanedbávání určitých řečových dovedností apod., metody před sebe kladly odlišné cíle. Metodisté vymezují 3 hlavní cíle výuky cizím jazykům (Rogova, 1991, s. 20-31): praktický, všeobecně vzdělávací a výchovný.

Praktický cíl představuje ovládnutí jazyka jako prostředku komunikace. Daný cíl může být výběrový (naprríklad zvládnutí schopností a dovedností mluvené řeči nebo čtení technické literatury atd.) a také komplexní (schopnost porozumět ústnímu projevu, mluvit, číst, psát v cizím jazyce). Všeobecně vzdělávací cíl se vztahuje na uvědomování si nejrůznějších způsobů vyjadřování myšlenek v cizích jazycích, což posiluje kognitivní procesy a rozvíjí řečové dovednosti žákủ. Za všeobecně vzdělávací cíl můžeme také považovat využití cizího jazyka pro zvýšení celkové úrovně kulturního rozvoje žáků, jejich znalostí kulturních zvláštností, tradic, dějin, zeměpisu, politické a ekonomické situace zemí studovaného cizího jazyka. Výchovný cíl výuky se projevuje ve formování osobnosti žáka, rozvoji společensky uznávaných morálních hodnot a etických zásad.

Každá vyučovací metoda tedy před sebe kladla určitý cíl nebo cíle, na jejichž základě se pak vybral vhodný prostředek jejich dosažení. Jedním z takových prostředků může být písemný text, který vystupuje $\mathrm{v}$ roli prŕkladu monologické či dialogické řeči, slouží k rozvoji schopnosti samostatného vyjadřování apod. Avšak text může ve vyučovacím procesu plnit i funkci samotného cíle a objektu zkoumání. Daný příspěvek je věnován právě roli psaného textu, jeho formám a míře využití v procesu výuky cizím jazykům podle té které vyučovací metody. Bylo vybráno několik metodických směrů, které obzvlášt’ výrazně ovlivnily vývoj současných metodik práce s textem.

\section{Analýzy vybraných metod $z$ hlediska vztahu k psanému textu}

\subsection{Gramaticko-prekladová metoda}

Podle Liškaře (1973, s. 67) je možno gramaticko-překladovou (syntetickou) metodu, která se ve školství uplatňovala od středověku téměř do konce 19. století, označit za první soustavný metodický systém vyučování cizím jazykům. Jelikož na vytváření daného metodického směru měla mimo jiné vliv i racionalistická filozofie 17. století, uplatňující zákony formální logiky, za základ vyučování cizím jazykům byl brán doslovný překlad z jazyka mateřského do jazyka cizího a z cizího do mateřského. Základním metodickým postupem byla dedukce a syntéza. Podle gramatických pravidel se uměle tvořily věty. Slovům se žáci učili izolovaně, mimo kontext. Forma se považovala za důležitější než vlastní význam vět.

Gramaticko-překladová metoda kladla hlavní důraz na vědomosti o jazyce, tj. na znalosti

z morfologie, syntaxe a lexika. Žáci se seznamovali s cizím jazykem na základě jeho psané podoby. Jazykový materiál byl, zejména na počátečním stupni, ilustrací gramatických pravidel a výjimek z nich. Cvičné věty spolu navzájem nesouvisely; převáděly se z jazyka do jazyka, aby byl dostatečně procvičen daný gramatický jev. Pozornost se kladla jenom na stavbu věty. Někteř́ metodisté, např́klad Bik (Bik, 1890) tvrdili, že obsahová stránka textů musí být nesmyslná, nelogická a občas odpuzující, aby se žáci soustředili na gramatickou stránku vět: Tento medvěd má synovce a neteř. Tyhle velbloudi napsali svi̊j úkol z ruského jazyka. Teprve později, na konci 18. století, se se vznikem nového typu gramatickopřekladové metody pod názvem metoda interlineární, meziřádková neboli textově-překladová začala číst díla klasiků. Její autor J. J. Jacotot (Hendrich a kol., 1988, s. 259) vycházel z předpokladu, že každé literární dílo obsahuje lexikální a gramatickou látku společnou i pro všechna ostatní díla, a proto podle jeho zásady „tou test dans tout" („vše ve všem“) je žák, který si osvojil lexikum a gramatiku jednoho textu, schopen přečíst si a pochopit jakýkoli jiný 
literární text. Jacotot vždy pracoval pouze $\mathrm{s}$ autentickými živými literárními texty $\mathrm{v}$ cizím jazyce, a to následujícím způsobem: žáci četli jednotlivé věty, napodobovali správnou výslovnost, prováděli analýzu vět a učili se jim nazpamět', čímž získávali mluvní návyky. Tak se text stal centrem práce s jazykem.

\subsection{Prímá metoda}

Koncem 19. století se objevuje silné reformní hnutí, které vyznává vyučování cizím jazykům přímou metodou, $v$ níž se v nové formě objevují zásady přirozené metody. Zastánci př́mé metody vystoupili proti všem typům gramaticko-překladové metody kvůli jejím nedokonalostem a cíli neodpovídajícím společenským požadavkům té doby. Podle Beneše (1970, s. 11, 15-16), největší ohlas vyvolaly snahy německého filologa Wilhelma Viëtora, který v roce 1882 publikoval monografii pod názvem „Der Sprachunterricht muß umkehren“ („Ve vyučování jazykům musí nastat obrat!“). Na první místo kladl požadavek, aby se při vyučování vycházelo ze skutečně živého jazyka, a ne ze psaných literárních textů. Viëtorovy návrhy došly brzy sluchu předních lingvistů jeho doby, jako byli O. Jespersen, H. Palmer, H. Sweet, Ch. Schweitzer, L. Ščerba.

Zatímco většina autorů považovala za cíl rozvoj plynulého ústního projevu a osvojení cizího jazyka pouze na základě jeho zvukové stránky, H. Sweet tvrdil (Miroljubov [online]), že cesta $\mathrm{k}$ úspěšné komunikaci vede přes zkoumání textů, které odráží skutečný mluvený jazyk. Sweet značně přispěl budoucímu rozvoji metodik čtení a vyvinul následující požadavky na učební texty:

- Texty musí být adaptovány a musí obsahovat opakování jazykové látky, což napomáhá zapamatování slov a gramatiky.

- Sweet odmítal „turistickou tématiku“ textů a navrhoval nejrůznější témata.

- Na počátečním stádiu výuky nabízel spíše popisové texty, jednoduché z hlediska mluvnice, potom ale postupně přidával texty s dialogickou řečí.

- Byla navržena gradace práce s textem.

Tato varianta př́mé metody byla modifikována po 1. Světové válce Haroldem Palmerem, který kromě rozvržení studia na určité stupně a metodického propracování požadavků na slovník, na výuku gramatiky a mluvení (Palmer, 1961, s. 11), také navrhnul kritéria výběru učebních textů pro výuku z hlediska jejich obsahu a jazykové stránky (Miroljubov [online]).

OBSAH:

- zajímavý a motivující obsah;

- dodržení zásady přiměřenosti věku žáků;

- využívání pouze známých reálií;

- upřednostnění textů s příběhem coby nejvhodnějším pro rozvoj ústní řeči.

JAZYK:

- Budování textů na pečlivě vybraném slovníku. Text by měl obsahovat do 90-95\% slov z daného slovníku v počátečním stádiu výuky a do 65-70 \% ve stadiu konečném.

- Při sestavení textů se musí brát ohled nejenom na počet slov, ale i na jejich význam.

- Text musí obsahovat neznámá slova, jejichž význam se dá odvodit z kontextu.

- Texty pro intenzivní čtení (s rozborem) musí obsahovat novou látku; texty pro extenzivní čtení (domácí) - pouze již vystudovanou látku a musí být jednodušší, než ty první.

Takto Sweet a Palmer značně racionalizovali proces výuky cizím jazykům. Jak píše Hendrich (1988, s. 263), přes všechny pozitivní prvky, jimiž se vyznačují modifikace přímé metody, je 
vidět, že všechny varianty tohoto metodického směru vyjadřují jednostranně zaměřený cíl jazykového vyučování. Hledala se proto metoda, která by odpovídala podmínkám při hromadném vyučování a vedle praktického komunikativního cíle plnila i výchovně vzdělávací úkol živých jazyků. Tak vznikla metoda cizojazyčného vyučování, která měla být syntézou metody syntetické a analytické - metoda zprostředkovací.

\subsection{Metoda čtení podle Michaela Westa}

Svůj systém výuky cizího jazyka pomocí čtení vypracoval Michael West v 20.-30. letech 20. století pro velkou bengálskou školu v Indii. Opíral se o názory zastánců př́mé metody, avšak považoval čtení za nejlepší způsob osvojení jazyka a rozvoj dovednosti ústního projevu nechával na poslední 2 roky studia. Svůj názor vybudoval na základě následujících tvrzení (Филолингвия [online]):

- Čtení je jediná dovednost, kterou se dá vyučovat zvlášt' od ostatních.

- Čtení je jednodušší než řeč, proto se žáci rychleji naučí jazyk.

- Po ovládnutí schopnosti číst a rozumět psanému slovu žák rychleji prožívá pocit úspěchu a je motivován $\mathrm{k}$ dalšímu studiu.

- Čtení je základním způsobem poznání kultury cizího národa.

- Čtením velkého množství textů se rozvíjí tzv. jazyková intuice.

- Jelikož výuka na základě čtení je jednodušší než na základě mluvení, nejsou kladeny velké požadavky na učitele.

Coby cíl výuky vidí West (1966) schopnost lehce číst v duchu a chápat obecný obsah textu bez zabývání se detaily. Proto West určil přesný objem neznámého lexika v textech čítanek: 1 nové slovo na 50-60 po sobě jdoucích slov textu, jelikož pouze tak neznámá slova nebudou vadit procesu čtení. V kurzu se používají jenom souvislé texty se zajímavým příběhem odpovídající věku a úrovni slovní zásoby žáků a motivující k dalšímu studiu, nikoli popisné texty o cizích kulturách a národech. Texty jsou adaptované, každému takovému textu předcházejí prredtextové otázky, na které pak žáci hledají odpovědi. Dále následují posttextová zadání zaměřená na ověření žákova pochopení obsahu textu.

Velkou zásluhou Westa je také vypracování celé řady knih a čítanek pro extenzivní čtení, které slouží př́kladem pro mnoho současných autorů. I když je zřejmé, že osvojení cizího jazyka pouze na základě čtení textů není možné, musíme uznat, že to byl právě Michael West, kdo tak značně přispěl k vývoji současných metodik čtení a práce s textem.

\subsection{Audioorální a audiovizuální strukturně globální metoda}

Období po druhé světové válce se vyznačovalo rozmachem technického rozvoje, vědeckého badání a vznikem nových telekomunikačních prostředků, což se nemohlo neodrazit i v oblasti vyučování cizím jazykům. Oproti předválečnému období se značně zvětšila potřeba ústní komunikace. Tím se dostává znovu do popředí jazykového vyučování zvuková stránka jazyka, dřive dosti zanedbávaná. Nejvíce úspěšní v tomto hledání byli američtí lingvisté, zejména Bloomfield a jeho dílo „Outline guide for the practical study of foreign languages” a také Ch. Fries a R. Lado. Jejich úsilí vyústilo v metodický směr, kterému se dostalo názvu audioorální (srov. Hendrich a kol., 1988, s. 266) neboli audiolingvální (Brooks, 1964, s. 201). V západní Evropě ukázala nový směr vyučování cizím jazykům metoda audiovizuální strukturně globální (Hendrich a kol., 1988, s. 266).

Cílem výuky bylo všestranné osvojení cizího jazyka, tj. osvojení všech druhů řečových dovedností. Většinou se proto používaly audio- nebo u audiovizuální metody video-nahrávky pro drilování výslovnosti. Jakákoliv teorie o jazyce nebo mateřský jazyk žáků se z procesu výuky vylučovaly jako rušivé elementy.

Přestože zastánci daných metod byli zásadně proti výuce dovednosti čtení (zejména $\mathrm{v}$ 
počátečném stádiu výuky), jako prostředků k osvojení ústního jazyka museli využívat psaných textů popisujících reálné každodenní situace s jistým zajímavým př́iběhem. Jako materiál k výuce sloužily převážně dialogy.

\subsection{Komunikativní metoda}

Po dlouhém hledání ideální metody, která by měla nejenom praktický cíl, ale i cíle výchovněvzdělávací, ve 2. polovině 20. století vznikla metoda komunikativní, která je jednou z variant smíšených metod a v současné době se považuje za dominantní. Důraz byl konečně převeden z učení se gramatickým pravidlům na komunikaci, na schopnost se dohovořit s rodilým mluvčím studovaného jazyka. Kromě principu komunikativnosti, je pro danou metodu charakteristické propojení všech forem ústní a písemní komunikace, což vedlo k nutnosti pečlivě vybírat učební texty. Co se týče témat, jsou to především informační texty o zemích studovaného jazyka a o kultuře daných zemí (literatuře, umění, vědě, businessu a financích apod.)

Další klíčovou zásadou komunikativní metody je využití neadaptovaných autentických textů připravených rodilými mluvčími (např́klad noviny, letáky, pohlednice, texty vědeckého zaměření nebo literární texty).

Ruská metodistka S. K. Folomkina (srov. Miroljubov, 2002, s. 384-385), která se zabývala komunikativní metodou v 70.-80. letech 20. století, formulovala požadavky na obsah a jazyk textu:

- ideologické zaměření textu a jeho výchovná hodnota;

- poznávací hodnota textu a vědeckost obsahu;

- shoda obsahu textu s věkovými zvláštnostmi žáků.

Co se týče jazyka, zdůrazňuje 2 zásady: v textech pro zběžné čtení se připouští obsah neznámých slovíček až do $25 \%$ na stránku, v textech pro podrobné čtení - 2-3 slova na stránku. Požadavky se však týkají pouze obsahu lexika a nezmiňují gramatiku, kompozici a jiné podstatné otázky. Kromě toho bychom mohli najít i jisté nedostatky v požadavcích na obsah. S. K. Folomkina zdůrazňuje důležitost ideologického zaměření textů, což svědčí o zastaralosti jejích požadavků. Nezabývá se otázkou rozvoje sociokulturních znalostí žáků, což je v rozporu s interkulturní zásadou současné varianty komunikativní metody.

Míra rozšiřrení počtu variant komunikativní metody po celém světě svědčí o jejím neustálém rozvoji.

\section{Literatura}

Beneš, E. et al. (1970). Metodika cizích jazyků. Praha: Státní pedagogické nakladatelství.

Brooks, N. (1964). Language and language learning. New York.

Hendrich, J. et al. (1988). Didaktika cizich jazyků. Praha: Státní pedagogické nakladatelství.

Liškař, Č. (1973). Cíl, obsah a metody vyučování cizim jazykưm. Brno: UJEP.

Бик, Е. (1890). Аналитико-синтетический метод обучения иностранным языкам. Русская школа. № 5. In Миролюбов, А. А. Грамматико-переводной метод. Думай Инглиш. Dostupné $\mathrm{z}$ http://www.domyenglish.ru/p75aa1.html

Миролюбов, А. А. (2002). История отечественной методики обучения иностранным языкам. Москва: Ступени, Инфра-М.

Миролюбов, А. А. Прямой метод. Думай Инглиш. Dostupné z http://www.domyenglish.ru/p72aa1.html

Миролюбов, А. А. Метод Палмера. Думай Инглии. Dostupné z http://www.domyenglish.ru/p69aa1.html

Палмер, Г. (1961). Устный метод обучения иностранным языкам: Монография по устным 
методам обучения иностранным языкам. Москва.

Рогова, Г. В. et al. (1991). Методика обучения иностранным языкам в средней школе. Москва: Просвещение.

Уэст, М. (1966). Обучение английскому языку в трудных условиях. Обучение английскому языку как иностранному и заметки по составлению учебников. Москва: Просвещение.

Филолингвия. (2011). Методическая система обучения чтению Майкла Уеста. Dostupné z http://filolingvia.com/publ/45-1-0-128

\section{Kontakt}

Mgr. Julia Caltová

Pedagogická fakulta, Univerzita Karlova

Katedra rusistiky a lingvodidaktiky

M. D. Rettigové 4, 11639 Praha 1

e-mail: j-gap@seznam.cz

\section{Bibliografické údaje}

Caltová, J. (2011). Historický vývoj úlohy psaného textu ve vybraných metodách vyučování cizím jazykům. In T. Janík, P. Knecht, \& S. Šebestová (Eds.), Smíšený design v pedagogickém výzkumu: Sbornik př́spěvkỉ z 19. výroční konference České asociace pedagogického výzkumu (s. 526-531). Brno: Masarykova univerzita.

Dostupné z: http://www.ped.muni.cz/capv2011/sbornikprispevku/caltova.pdf doi: 10.5817/PdF.P210-CAPV-2012-4 